\title{
Türkiye'de Politik İstikrarsızlık ile Ekonomik Büyüme İlişkisi: Bir Nedensellik Analizi $^{*}$
}

\section{Selim Şanlısoy ${ }^{* *}$}

O̊z

Bu çalışmanın hedefi Türkiye'de 1987 - 2015 döneminde politik istikrarsızlık ile ekonomik büyüme arasındaki nedensellik ilişkisinin varlığını araştırmaktır. Bu amaçla gerçekleştirilen simetrik ve asimetrik nedensellik testlerinin sonucunda literatürden farklı olarak ekonomik büyümede meydana gelen pozitif şokların politik istikrarsızlık üzerinde pozitif şok yarattığı bulgusuna ulaşılmıştır. Bu durum gerek bölüşüm ilişkileri çerçevesinde ülke içindeki çıkar çatışmalarına gerekse Türkiye'nin jeopolitik ve jeostratejik önemi dikkate alındığında rakip ülkelerin Türkiye’nin gücünü zayıflatıcı yöndeki girişimleriyle açıklanabilir. Bu noktadan hareketle daha hızlı büyüyen ve gelişen bir Türkiye için dış güçlere karşı kararlı duruş sergileyen kamusal iktidarın ve politik alanda uzlaşma ve hoşgörü kültürünün egemen kılınmasının önemli olduğu ifade edilebilir. Bu unsurlar Türkiye ekonomisinin yapısal sorunlarını ortadan kaldırıcı politikalarla birleştirildiğinde bölgesel anlamda Türkiye’yi öncü kılan yeni bir güç dengesi oluşturulabilecektir.

\section{Anahtar Kelimeler}

Politik istikrarsızlık, ekonomik büyüme, Hacker-Hatemi-J Nedensellik Testi, Hatemi-J Asimetrik Nedensellik Testi.

JEL Sinıflaması: E6, H1, O4

\footnotetext{
Geliş Tarihi: 10 Ekim 2016 - Kabul Tarihi: 04 Temmuz 2017 Bu makaleyi şu şekilde kaynak gösterebilirsiniz: Şanlısoy, Selim (2020). “Türkiye’de Politik İstikrarsızlık ile Ekonomik Büyüme İlişkisi: Bir Nedensellik Analizi”. bilig - Türk Dünyast Sosyal Bilimler Dergisi 92: 85-114.

${ }^{*}$ Doç. Dr., Dokuz Eylül Üniversitesi, İİBF, İktisat Bölümü - İzmir/Türkiye ORCID ID: orcid.org/0000-0002-0629-0905

selim.sanlisoy@deu.edu.tr
} 


\section{Giriş}

1990'lı yıllardan sonra gelişmiş ve gelişmekte olan ülkelerin makro ekonomik performans farklılıklarının açıklanmasında politik ve kurumsal faktörler daha fazla dikkate alınmaya başlanmıştır. Politik değişkenlerin ülkelerin ekonomik performansları üzerindeki etkisini araştırmaya yönelik çalışmalarda politik rejim tipi, dikkate alınan ilk değişken olmuştur. Böylece demokrasi, ülkelerin gelişmişlik farklılıklarını açıklamada bir değişken ya da ölçüt olarak kullanılmaya başlanmıştır. Demokrasinin bir değişken olarak ele alınmasının en önemli nedeni güçlü kurumsal yapıların ekonomik gelişmenin sağlanmasında belirleyici olduğunun ve söz konusu kurumsal yapılanmanın da demokratik rejimlerde kurulabileceğinin düşünülmesidir. Öte yandan ülkelerin politik yapılanmaları incelendiğinde gelişmiş ülkelerde demokratik sistemlerin; gelişmekte olan ülkelerde ise antidemokratik sistemlerin bulunduğu veya demokrasinin yeterince kurumsallaşmadığı görülmektedir. Bunun neticesinde, politik sistem farklılıklarının ülkelerin ekonomik performanslarını belirleyen bir etken olarak ele alınmıştır. Bununla birlikte literatürde politik sistem farklılıklarının ekonomik performans üzerindeki etkisi hakkında kesin bir bulguya ulaşılamamıştır. Söz konusu sonuç, ekonomik performansı belirleme olasılığına sahip alternatif faktör arayışlarını da beraberinde getirmiştir. Böylece literatürde politik istikrarsızlık, makroekonomik performansı etkileyen politik değişkenlerden biri olarak kullanılmaya başlanmıştır. Dolayısıyla ekonomik gelişmişlik farklılıklarının belirlenmesinde politik sistem farklılıklarından ziyade, mevcut sistemin istikrarı, belirleyici unsur olarak öne çıkmıştır (Telatar 2003: 73-74). Tüm bunlarla birlikte demokrasilerde politik istikrarsızlığın meydana gelme olasılığ ratik rejimlere göre daha düşüktür. Çünkü demokratik sistemler, içerisinde barındırdığı uzlaşma ve hoşgörü kültürüne bağlı olarak toplumda ortaya çıkan iç çatışmaların şiddetini düşürerek çatışmaların politik krizlere ve dolayısıyla ekonomik krizlere neden olmasının önüne geçmektedir (UNDP 2002: 57).

Politik istikrarsızlık beraberinde getirdiği politik belirsizlik ve risk ortamıyla ekonomik aktörlerin gelecek ufkunu sınırlamakta, ekonomik birimlerin beklentilerini etkileyerek ekonomik değişkenler üzerinde belirleyici olmaktadır. Dolayısıyla politik istikrar/istikrarsızlık bir yandan makro diğer yandan mikro ekonomik boyutlarda etkili olmaktadır. Bu çalışmada öncelik- 
le politik istikrarsızlık ve kaynakları hakkında bilgi verilecek ve ardından politik istikrarsılıkla büyüme arasındaki ilişkiler teorik olarak açıklanmaya çalışılacaktır. Daha sonra Türkiye ekonomisi örneği çerçevesinde politik istikrarsızlıkla ekonomik büyüme arasındaki nedensellik ilişkisinin varlığı ekonometrik analizler yardımıyla araştırılacaktır. Hipotez testlerinden elde edilen bulgulara göre sonuç ve ekonomi politikası önerileriyle çalışma son bulacaktır.

\section{Politik İstikrarsızlık}

Türk Dil Kurumu istikrar kavramını "aynı biçimde sürme, devam etme, kararlılık" şeklinde tanımlarken; istikrarsızlık ise istikrarın olmaması durumu olarak tanımlanmaktadır. Bu durumda politik istikrarsızlık, politik alanda ortaya çıkan kararsızlık ya da değişken yapısal koşullar olarak düşünülebilir. Bu noktadan hareketle politik istikrarsızlık farklı rejim tipleri için söz konusu olabilir.

Politik rejim tiplerinin ve uygulama süreçlerinin farklılıklarına bağlı olarak gerek bir kavram birliğinin oluşturulması noktasında gerekse kaynakları noktasında politik istikrarsızlık üzerinde görüş birliği sağlanabilmiş değildir. Bununla beraber politik istikrarsızlık kavramında iki durum ön plana çıkmaktadır. Bunlardan birincisi ülkede geçerli olan politik sistemi zorla değiştirmeye çalışma; ikincisi anayasal düzen içinde kalmakla beraber politik süreçte meydana gelen (seçmenlerin kutuplaşması, politik parçalanma, koalisyon ya da azınlık hükümetleri, hükümetlerin değişim sıklığı vb.) politik olgulardır.

Alesina ve Perotti (1993: 3)'ye göre politik istikrarsızlık;

- Anayasal olan veya olmayan hükümet değişiklikleri,

- Sosyal huzursuzluk ve politik şiddet,

başlıkları altında toplanmaktadır. Söz konusu başlıklar dikkate alındığında politik istikrarsızlığın gerek demokratik sistemlerde gerekse otokratik yönetim biçimlerinde meydana gelebileceği daha iyi anlaşılmaktadır. Otokratik yönetim biçimlerinde istikrar egemenlik gücünü elinde tutan kişiye bağlıdır. Söz konusu kişinin devrilmesi, iktidardan uzaklaştırılması, ölmesi vb. durumlar istikrarsızlığı meydana getirir (Yayla’dan aktaran Öztürk 2004: 6). Yayla, politik istikrarsızlığın kaynağını egemen kişiye bağlamış olsa da 
demokratik sistemlerde ortaya çıkan savaş, terör, sınır çatışmaları gibi bazı politik istikrarsızlık kaynaklarının otokratik sistemlerde de görülme olasılı̆̆ 1 bulunmaktadır. Demokratik sistemlerde ise politik istikrarsızlık kaynakları genellikle aşağıdaki durumlarda meydana gelmektedir (Eren ve Bildirici 2001: 31):

- Parlamentonun kutuplaşması,

- Koalisyon hükümetleri,

- Seçmenlerin kararsızlığı,

- Seçimlerin idaresi ve zamanlaması,

- Hükümet değişikliklerinin sıklığı.

İncelenen dönem dikkate alındığında Türkiye, politik istikrasızlığın yoğun şekilde görüldüğü bir ülke olarak ele alınabilir. Söz konusu dönemde Türkiye'de yaşanan politik istikrasılıkların kaynakları (Şanlısoy ve Kök 2010a: 103, Yalçınkaya vd. 2016: 164-165):

- İncelenen dönemde politik istikrarsızlığın önemli kaynaklarından biri askeri müdahalelerdir. Askeri müdahale; askeri darbeden farklı bir kavram olup silahlı kuvvetlerin özellikle hükümet ve parlamento üzerinde yazılı ve sözlü beyanlarla baskılar kurarak belli kararların alınmasına ve hükümet değişikliklerine neden olacak şekilde müdahalelerde bulunmasını ifade etmektedir (Tan 2008: 2). Söz konusu dönemde 28 Şubat 1997 ve 27 Nisan 2007 tarihlerinde askeri müdahale yaşanmıştır. Her iki müdahale sonrasında makro ekonomik performansta olumsuz bir gidişat ortaya çıkmıştır (Özsağır 2013: 765-766).

- $\quad$ Ekonomi politikasının yürütülmesindeki başarısızlıklar ve politik aktörlerin adlarının karıştığı yolsuzluklar, politik alana ve politikacılara duyulan güveninin azalmasını beraberinde getirmiştir. Bu durum bir süre sonra seçmenlerin sürekli olarak bir arayış içerisine girmelerine neden olmuştur. Tüm bunlar politik parçalanmayı beraberinde getirerek 1991 ile 2002 yılları arasında bir yandan güçsüz diğer yandan sürekli olarak uyum sorunu yaşayan koalisyon hükümetlerinin iktidara gelmesine sebep olmuştur. Seçmenlerle ilgili ortaya çıkan bir başka sorun ise 1980'e kadar özellikle toplumda sağ-sol şeklindeki kutuplaşma, 1980'den sonra laik - antilaik kutuplaşması şeklinde görülmeye başlanmıştır. Söz konusu kutuplaşma, daha 
doğrusu antilaik grubun varlığı devlet için bir tehlike olarak görülerek askeri müdahalelerin ana nedenini oluşturmuştur. Ayrıca bu durum, 2002 sonrasında tek başına iktidara gelen Adalet ve Kalkınma Partisi'nin özellikle ilk dönemlerinde söz konusu partinin anti laik eğilimleri barındırdığı gerekçesi ile potansiyel bir müdahale olasılığının varlığını da beraberinde getirmiştir. Dolayısıyla askeri müdahale olma olasılığı bir politik istikrarsızlık kaynağı olmuştur.

- Kurulan hükümetlerin neredeyse hiçbiri ömrünü tamamlayamamış ve 2011 ve 2015 Haziran seçimleri dışındaki seçimlerin tümü erken seçim olmuştur. Ancak Haziran 2015 seçimleri sonrasında kalıcı bir hükümetin kurulamamış olması erken seçimi gündeme getirmiş ve Kasım 2015'te erken seçim yapılması kararı alınmıştır. Ayrıca incelenen dönemde hükümetlerin ortalama ömürleri oldukça kısa olmuştur. 1987-2016 dönemi dikkate alındığında 20 hükümet (46. ve 65. Hükümetler dâhil) kurulmuş ve ortalama hükümet ömrü yaklaşık 1 yıl 5 ay olarak gerçekleşmiştir. Ayrıca bir taraftan hükümet değişikliklerinin diğer taraftan seçimlerin (milletvekilliği genel seçimleri ve yerel seçimler) sıklığı, hem ekonominin politik manipülasyonuna hem de politik istikrarsızlığa neden olarak ekonomik sorunlara kalıcı önlemler alınmasını zorlaştırmıştır. 2002 yılında iktidara gelen Adalet ve Kalkınma Partisi göreceli olarak sağlanan politik istikrar ortamının ve tek başına iktidar olmanın da etkisiyle özellikle ilk döneminde (2002-2007) önemli reformları gerçekleştirmiştir. Böylece gerek ekonomik büyüme gerekse makro ekonomik performans açısından önemli başarılar elde etmiştir (Acemoğlu ve Üçer 2015: 2).

- Dönem içerisinde özellikle PKK terör örgütünün faaliyetleri olmak üzere yaşanan terör olayları,

- Gezi Parkı Olayları: Söz konusu olaylar, Mayıs 2013’ün sonunda İstanbul'da Taksim Meydanı Yayalaştırma Projesi kapsamında ilk etapta ağaç kesilmesine karşı bir eylem olarak başlayan ancak daha sonra AKP iktidarı karşıtı protestolara dönüşerek diğer illere de yayılan bir süreci ifade etmektedir. Çevreci bir duyarlılıkla başlayan eylemler ilerleyen aşamada aşırı örgütlerin, bölgesel ve küresel ölçekteki dinamiklerin de etkisiyle kontrolden çıkmış ve dış aktörler tarafından yönlendirilebilecek bir güvenlik problemine dönüşmüştür (Sandıklı 2013). 
- $\quad$ Paralel devlet soruşturmaları: Başbakan Erdoğan 2010 yılında bürokraside Gülen cemaatinin varlığını fark ederek bunların bürokrasi içerisindeki gücünü sınırlamak için adımlar atmaya başlamıştır. Bunun üzerine daha sonra Fethullahçı Terör Örgütü olarak adlandırılacak terör örgütü, hükümeti düşürmek için MİT Müsteşarı Hakan Fidan’n ifadeye çağrılmas1, Gezi Parkı Olayları'nın kullanılması, 17-25 Aralık'ta Emniyet ve yarg1 içerisindeki uzantılarının kullanılmasıyla bir takım operasyonlara giriştiyse de başarısız olmuştur (Yayla 2016: 167). Tüm bunlara karşın İstanbul 1. Sulh Ceza Hâkimliği'nin 19 Aralık 2014 tarihli kararı ile "Silahlı Terör Örgütü Kurma veya Yönetmek” ve "Paralel Devlet Yapılanması” oluşturmak suçlamalarından Fethullah Gülen hakkında yakalama kararı çıkarılmıştır. Ardından 11 Aralık 2015'de Ankara Cumhuriyet Başsavcılığı'nın talimatıyla iddianamede geçen adıyla "Fethullahçı Terör Örgütü/Paralel Devlet Yapılanması"na yönelik Türkiye genelinde operasyonlar başlatılmıştır.

- Dış kaynaklı istikrarsızlık ortamı: Politik istikrarsızlık yalnızca yurtiçinde yaşanan sorunlara bağlı olarak ortaya çıkmamakta; başta komşu ülkeler olmak üzere diğer ülkelerle ilgili olarak da meydana gelebilmektedir. Bu bağlamda Türkiye’nin bir yandan komşuları ile arasında ortaya çıkan problemler diğer yandan içinde bulunulan coğrafyanın devamlı olarak problemler doğurması da Türkiye açısından politik istikrarsızlığın önemli kaynaklarından birini meydana getirmektedir. Dolayısıyla Irak ve Suriye’de meydana gelen karışıklıklar, Rusya ile Türkiye arasında yaşanan sorunlar ve DEAŞ terör örgütünün faaliyetleri son zamanlardaki en önemli dış kaynaklı politik istikrarsızlık unsurları olarak görülebilir.

- Dış kaynaklı bir başka politik istikrarsızlık öğesi ise Türkiye’nin jeopolitik ve jeostratejik önemine bağlı olarak da açıklanabilir. Türkiye'nin jeopolitik ve jeostratejik önemi dikkate alındığında gerek komşu ülkeler gerekse birçok gelişmiş ülke, bölgede güçlü ve söz sahibi bir Türkiye istememektedirler. Buna bağlı olarak da özellikle ülkedeki terör odaklarını besleyerek ya da söz konusu terör örgütü mensuplarını devlet mekanizması içerisine yerleştirerek politik istikrarsızlığa neden olmaktadırlar (Atay 2008: 421-424, Arınç 2010: 6-10). Böylece Türkiye’yi zayıflatmaya çalışmaktadirlar.

Tüm bu olaylar ve süreçler dikkate alındığında ele alınan dönem açısından Türkiye’nin farklı kaynaklardan beslenen bir politik istikrarsılık problemi- 
nin olduğu söylenebilir. Bu durum Türkiye'nin gelişmesinin ve refah artışının önündeki önemli engellerden biri olarak düşünülebilir.

\section{Politik İstikrarsızlık - Ekonomik Büyüme İlişkisi}

Esas itibariyle ekonomik değişkenlerle politik değişkenlerin birbirlerini etkileme olasılıkları hemen her zaman bulunmaktadır. Platon, ülkede servet dağılımının adil olmamasının toplumda huzuru bozacağını, sınıf çatışmalarını ortaya çıkaracağını MÖ 4.yy'da ifade etmiştir. Bu çalışmanın özelinde tüm politik ve ekonomik değişkenlerin etkileşimlerinden ziyade, ekonomik büyüme ile politik istikrarsızlığın birbirlerini etkileme mekanizmaları ortaya konulmaya çalışılacaktır.

Politik istikrarsızlığın ekonomik büyüme üzerine etkileri gerek direkt gerekse dolaylı kanallar üzerinden ortaya çıkabilmektedir. Politik istikrarsızlığın ekonomik büyüme üzerindeki dolaylı kanal üzerinden etkisi, bilhassa geleceğe ilişkin belirsizlik ortamı yaratmasına bağlı olarak ortaya çımaktadır. Politik istikrarın bulunması girişimcilerin geleceği daha doğru bir şekilde tahmin edebilmelerini sağlayarak daha uzun dönemli ve kalıcı ekonomik faaliyetlere yönelmesine yol açmaktadır (İnsel 1991: 19-20).

Politik istikrarsızlık hukuksal düzende zayıflı̆ı beraberinde getirerek mülkiyet haklarının güvence altına alınmasını zorlaştırmaktadır. Mülkiyet haklarının korunmasına ilişkin kaygıların bulunması, sermayenin marjinal verimliliğiyle yatırımcıların elde edebilecekleri getiriler arasında bir farklılık oluşturmaktadır. Bu farklılık sermayenin marjinal verimliliği dikkate alındığında aynı koşullardaki ülkelerin yatırım ve ekonomik büyüme oranları arasındaki farklılıkları belirleyen ana öğe olabilmektedir. Ayrıca fikri ve sınai mülkiyet haklarına duyarlı olan doğrudan yabancı sermaye yatırımlarının ülkeye girişi yavaşlamaktadır. Bu durum özellikle tasarruf açığı bulunan gelişmekte olan ülkeler açısından sorun olmakta ve büyüme oranının potansiyelin altında kalmasına neden olmaktadır.

Politik istikrarsızlık, geleceğe ilişkin bir belirsizlik ortamı yarattığından yatırımlardan beklenen getirinin ve dolayısıyla yatırımların düşmesine yol açabilmektedir (Leahy \& Whited 1996: 64, Asteriou \& Price 2001: 386). Böylece büyümenin potansiyelinden daha düşük bir seviyede gerçekleşmesine neden olmaktadır.

Söz konusu belirsizlik ortamı politikacıları da etkilemektedir. Bir sonraki 
seçimlerde tekrar iktidarı elde edip edemeyeceğini öngöremeyen iktidarlar bir taraftan giderek daha fazla rant kollama faaliyetlerine yönelirlerken diğer taraftan tekrar iktidara gelebilmek için daha fazla popülist politikalar uygulamayı tercih edebilirler. Bu şekilde ekonomik kaynakların verimliliği düşük ya da verimsiz alanlara aktarılması, bir taraftan ekonomik büyümenin olumsuz şekilde etkilenmesine yol açarken diğer taraftan da ekonomide enflasyonist bir eğilimin ortaya çıkmasına veya mevcut problemlerin daha da büyümesine sebep olabilmektedir. Bu durum ülkede mevcut olan belirsizliğin daha da artmasına yol açabilmektedir. Ayrıca politik istikrarsızlık, para ve maliye otoritelerinin kısa vadeli düşünerek uzun vadeli etkileri olmayan kararlar almalarına neden olmaktadır (Karahan ve Karagöl 2014: 1). Böylece ekonomik karar birimleri de olumsuz yönde etkilenmektedir. Gerek reel sektördeki gerekse finansal sektördeki karar birimleri riskten kaçınarak kaynak dağılımının etkinsiz bir şekilde gerçekleşmesine neden olmaktadır (Kök vd. 2015: 168). Bu durum büyümenin potansiyelin altında kalmasını da beraberinde getirmektedir.

Politik istikrarsızlık ortamında bir yandan belirsizliğin diğer yandan risk priminin artmasıyla borçların hem ortalama vadesi kısalmakta hem de faiz oranı bir başka ifadeyle maliyeti artmaktadır. Bu durum gerek kamusal gerekse özel kesim borçlanması üzerinde etkili olarak büyümeyi olumsuz yönde etkileyebilmektedir. Çünkü borçlanma maliyetlerindeki artış kamunun, verimli yatırımlardan ziyade borç ve faiz ödemelerine daha fazla kaynak aktarmasına neden olacaktır. Özel sektör ise kredi maliyetlerindeki artış çerçevesinde yatırım miktarlarını azaltabilir.

Yurtiçinden yurtdışına doğru gerçekleşen sermaye çıkışları politik istikrarsızlığın büyüme üzerindeki etki kanallarından bir diğerini oluşturmaktadir. Politik istikrarsızlık durumunda hem fiziki hem de finansal sermaye kendisini daha güvende hissedeceği ülkelere akmaktadır (Lensink vd. 2000: 87). Özellikle 1980 'li yıllardan itibaren giderek hız kazanan küreselleşmeyle birlikte gelişmekte olan ülkeler yabancı sermaye yatırımlarını çekebilmek için rakip konuma gelmişlerdir. Dolayısıyla yabancı sermayenin ülkeye çekilebilmesi ya da ülkede tutulabilmesi için de politik istikrarın sağlanması giderek daha fazla önem kazanmıştır. Aksi takdirde sermaye stokunda yaşanacak bir düşüş, büyüme oranını doğrudan düşürücü etki yapabileceği gibi dolaylı yoldan da sermaye mallarının ve borçlanmanın maliyetlerinde bir 
artışa neden olarak büyüme oranını azaltabilecektir. Politik istikrarsılı̆̆a bağlı olarak meydana gelen belirsizlik durumunda yatırımcıların kararlarında olumsuz beklentilerin yanı sıra ülkedeki yabancı finansal sermaye hızla ülkeyi terk etmektedir. Bu, ekonomik krizlere ya da var olan ekonomik sorunların daha da derinleşmesine yol açmaktadır. Sonuç olarak, politik istikrarsızlı̆̆ın ortaya çıkardığı belirsizlik ortamı yüksek riskten kaçınan ekonomik birimlerin iktisadi faaliyetleri üzerinde daraltıcı etki yapmakta ya da dış piyasalara yatırımı özendirerek ülkeden sermaye çıkışını hızlandırmaktadır (Alesina vd. 1996: 193-194)

Günümüzde büyüme sürecinde beşeri sermayenin rolü giderek artmaktadır. Romer (1996: 137), İçsel Büyüme Teorisi kapsamında beşeri sermayeyi ülkelerin büyüme oranları ve gelir farklılıklarını açıklayan bir değişken olarak belirtmektedir. Politik istikrarsıllığın büyüme üzerindeki etkilerine ilişkin bir başka kanal beyin göçü veya beşeri sermaye göçüne bağlı olarak oluşmaktadır. Örneğin, Tansel ve Güngör (2003: 704), Türkiye örneğini dikkate aldıkları çalışmalarında beyin göçünün nedeninin yurtdışına eğitime giden öğrenciler için yurtdışındaki sistemli ve düzenli yaşam tarzı olduğu, yurtdışında çalışanların Türkiye'ye geri dönmemesinin nedeninin ise ülkede yaşanan ekonomik ve politik istikrarsızlıklar olduğu sonucuna ulaşmışlardır. Özellikle bilgi ekonomisine geçişin yaşandığı günümüzde bir üretim faktörü olarak beşeri sermayenin önemi giderek artmaktadır. Nitekim günümüzde temel ürün olan yenilikleri yaratan ve bilgi üretimini gerçekleştiren beşeri sermayedir. Beşeri sermayenin politik istikrarsızlığın yaşandığı ülkelerden istikrarın bulunduğu ülkelere doğru akması bir yandan istikrarsızlığın yaşandığı ülkelerde ekonomik büyümenin potansiyelinin altında kalınmasına neden olurken diğer yandan ülkeler arası kaynak transferini de ortaya çıkarmış olacaktır.

Politik istikrarsızlık ortamında yaşanan yetersiz büyümeye bağlı olarak vergi gelirlerinde dolayısıyla kamu gelirlerinde bir azalma ortaya çıkacaktır. Bu durum, kamu harcamalarının finansmanına ilişkin problemleri de beraberinde getirecektir. Kamu harcamalarıla gelirleri arasındaki dengesizlik, bütçe açıklarının ve kamu borçlanmasının artışıyla sonuçlanacaktır. Ayrıca tekrar seçilmeyi hedefleyen iktidarların kısa vadeli politikalar izlemesi de kamu borçlarının artmasına neden olabilmektedir (Persson \& Tabellini 2002: 366-367). Grilli vd. (1991: 349) tarafindan da belirtildiği üzere bu durum 
kamu gelirlerinin yeterince artırılamamasına bağlı olarak bütçe açıklarını artıracaktır. Kamu borçlanmasındaki artış daha önce belirtilen mekanizmalarla tekrar büyümenin yavaşlamasını beraberinde getirecektir.

Politik istikrarsızlı̆ın ifade edilen kanal ve mekanizmalarla büyüme üzerinde olumsuz etkiler ortaya çıkarmasının yanı sıra değişkenler arasındaki ilişkinin ters yönlü olarak da meydana gelmesi mümkündür. Bir başka ifade ile büyüme oranlarının düşük kalması ya da düşmesi halkın refah seviyesini düşürerek politik istikrarsızlığı ortaya çıkarabilir. Burada ilk kanal, düşük büyüme oranı nedeniyle hükümetlerin değişme olasılıklarının artmasına bağlı olarak oluşmaktadır. Bu durum ise politik konjonktür teorileri kapsamında ortaya konulan iktidarların tekrar seçilme olasılıklarının seçimlerin hemen öncesindeki ekonomi yönetimindeki başarısıyla doğru yönlü bir ilişki içerisinde olmasıyla bağlantılıdır. Seçimlerin hemen öncesindeki büyüme performansının kötü olmasına bağlı olarak hükümetlerin değişim sıklığı ve erken seçim olasılığı yükselmektedir. Demokratik sistemlerden farklı olarak otokratik sistemlerdeyse düşük büyüme oranı halkın hoşnutsuzluğunu artırarak; iktidar karşıtı faaliyetlere girişme eğilimlerine zemin hazırlayarak darbe veya devrimlere uygun bir ortam meydana getirmektedir (Telatar 2003: 76-77).

İkinci olarak, Kuznets (1955) tarafından belirtildiği üzere ekonomik büyüme özellikle ekonomik gelişmenin ilk safhalarında gelir dağılımında eşitsizlikler yaratabilmektedir. Bu noktadan hareketle ekonomik büyüme farklı çıkar grupları arasında güç dengesinin yeniden dağılımını beraberinde getirebilir. Böylece söz konusu çıkar grupları arasında bölüşüm çatışmalarını ortaya çıkararak politik istikrarsızlığı artırabilecektir. Öte yandan böyle bir dönemde eğer iktidarda koalisyon hükümeti varsa bölüşüm ilişkilerinin önemli değişimleri gerektirebileceğinden koalisyon hükümetlerinin dağılmasına yol açarak politik istikrarsızlı̆̆ı artırabileceği söylenebilir. Bununla birlikte olgu, koalisyon hükümetlerinde farklı çıkar grupları arasında uzlaşmaya varılmasına bağlı olarak sağlanabilecek güç dengesi açısından ele alındığında, koalisyon hükümetlerinin sosyal ve politik gerilimleri düşürerek daha yüksek büyüme oranlarını gerçekleştirebileceği de düşünülebilir (Campos ve Nugent 2002: 158). Fakat bu durumda politik istikrar, farklı çıkar grupları arasında hükümet düzeyinde gerçekleştirilebilecek uzlaşmaya bağlı olacaktır. Bu konunun bir başka boyutu ekonomide ortaya çıacak 
yolsuzluk ortamı ile ilgilidir. Politik istikrarsızlık ortamlarında kurumsallaşma süreçleri sekteye uğradığından yolsuzluklar artma eğilimi içerisine girmektedir (Erkal vd. 2015: 327). Ayrıca Murphy vd. (1991)'nin belirttiği üzere iktidarlarını kaybetme tehdidi ile karşı karşıya olan zayıf hükümetler baskı ve çıkar gruplarının rant kollama faaliyetlerine daha fazla maruz kalmaktadırlar. Bu durumda yolsuzluklar, fırsat eşitsizlikleri yaratarak ve/veya rant kollama faaliyetlerini artırarak ya ekonomide yeni baskı ve çıkar grupları oluşturmakta ya da var olanların belli bir kısmını güçlendirmektedir. Bu güçlenme ülke içinde gelir ve servet dağılımında eşitsizlikleri artırarak politik istikrarsızlığı daha da yükseltmektedir (Mo 2001: 66-67).

Sonuç olarak gerek teorik gerekse ampirik çalışmalarda politik istikrarsızlık ile ekonomik büyüme arasında karşılıklı bir nedensellik ilişkinin bulunduğu görülmektedir. Politik istikrarsızlık ile ekonomik büyüme arasındaki ilişkiyi araştıran çalışmalar aşağıda Tablo 1'de özetlenmiştir.

Tablo 1. Politik İstikrarsizlık-Ekonomik Büyüme İlişkisi Literatür Özeti

\begin{tabular}{|c|c|c|c|c|}
\hline Çalışma & Dönem & Ülke & $\begin{array}{l}\text { Politik İstikrar- } \\
\text { sızlık Ölçüttü }\end{array}$ & Bulgu \\
\hline $\begin{array}{l}\text { Parlakyıldız } \\
(2015)\end{array}$ & $1999-2013$ & 25 Ülke & Yurtiçi Çatışma & $\begin{array}{l}\text { Politik istikrarsılık bü- } \\
\text { yümeyi olumsuz yönde } \\
\text { etkilemektedir }\end{array}$ \\
\hline $\begin{array}{l}\text { Artan ve } \\
\text { Hayaloğlu } \\
(2014)\end{array}$ & $1972-2009$ & Türkiye & $\begin{array}{l}\text { Politik özgür- } \\
\text { lükler }\end{array}$ & $\begin{array}{l}\text { Politik özgürlüklerin } \\
\text { düzeyi büyümeyi uzun } \\
\text { dönemde olumlu yönde } \\
\text { etkilemektedir. }\end{array}$ \\
\hline $\begin{array}{l}\text { Aisen ve } \\
\text { Veiga (2013) }\end{array}$ & $1960-2004$ & 169 Ülke & $\begin{array}{l}\text { Kabine değişik- } \\
\text { likleri }\end{array}$ & $\begin{array}{l}\text { Büyüme oranı ile ters } \\
\text { yönlü ilişki bulunmuş- } \\
\text { tur. }\end{array}$ \\
\hline $\begin{array}{l}\text { Goesjenova } \\
\text { (2013) }\end{array}$ & $1976-2007$ & Türkiye & $\begin{array}{l}\text { Politik İstikrar- } \\
\text { sızlık ve Etnik } \\
\text { Çatışma }\end{array}$ & $\begin{array}{l}\text { Politik istikrarsızlık ve } \\
\text { etnik çatışma, KBGS- } \\
\text { YH üzerinde olumlu } \\
\text { etki yaratmaktadır. }\end{array}$ \\
\hline $\begin{array}{l}\text { Jarosiewicz } \\
(2013)\end{array}$ & $2002-2011$ & Türkiye & $\begin{array}{l}\text { Sosyo-politik } \\
\text { İstikrar }\end{array}$ & $\begin{array}{l}\text { Sosyo-politik istikrar } \\
\text { ekonomik değişkenleri } \\
\text { olumlu yönde etkile- } \\
\text { mektedir. }\end{array}$ \\
\hline $\begin{array}{l}\text { Gür ve Ak- } \\
\text { bulut (2012) }\end{array}$ & $1986-2003$ & 19 Ülke & $\begin{array}{l}\text { Politik İstikrar } \\
\text { Endeksi }\end{array}$ & $\begin{array}{l}\text { Politik istikrar büyü- } \\
\text { meyi olumlu yönde } \\
\text { etkilemektedir. }\end{array}$ \\
\hline
\end{tabular}


Arslan

(2011)

1987-2007 Türkiye

Demirgil

(2011)

Şanlısoy ve

Kök (2010a)

Şanlisoy

ve Kök

(2010b)
1970-2006 Türkiye

Politik İstikrarsızlık Göstergeleri

1987-2006 Türkiye

Politik Risk Endeksi

1985-2004 62 Ülke

Politik Risk Endeksi
Politik İstikrar-

sızlık Endeksi

GSYH'dan politik istikrarsızlığa tek yönlü nedensellik

Politik istikrarsızlık büyümeyi olumsuz yönde etkilemekte

GSYH'dan politik istikrarsızlığa tek yönlü nedensellik

Politik istikrarsızlık belli bir düzeyi aştı̆̆ında büyümenin nispi olarak azaldığı, ilgili ülkenin yapısına, sorunlarını aşma kapasitesine bağlı olarak istikrarsızlık belli bir düzeye çekildiğinde ise büyümenin olumlu yönde bir gelişme sergilediği sonucuna ulaşılmıştır

Butkiewicz 1970-1997 100 Ülke Hükümet İstik(2005) rarsızlıkları, politik şiddet

Hükümet istikrarsızl1ğının ve sosyal istikrarsızlığın büyüme üzerine etkisinin önemsiz, politik şiddet göstergelerinin ise önemli ve negatif etkisinin olduğu hesaplanmıştır

Sakamato

1961-1998 17 Ülke

Politik İstikrarsızlık Endeksi

GSYH'dan politik istikrarsızlığa doğru tek yönlü nedensellik

Telatar ve 1951-2001 Türkiye

Askeri müdahale olma olasılığı

(2004)

Telatar

1986-2001 Türkiye (2003)

Politika değişkenliği (döviz kuru değişkenliği)
Düşük büyüme oranının siyasal rejim değişikliği olasılığını dolayısıyla siyasal istikrarsızlığı artırdığı sonucuna ulaşmışlardır Düşük büyüme oranı siyasal istikrarsızlığı artırmakta 


\begin{tabular}{|c|c|c|c|c|}
\hline $\begin{array}{l}\text { Kurzman } \\
\text { vd. (2002) }\end{array}$ & $1951-1980$ & 106 Ülke & İsyan & $\begin{array}{l}\text { Politik istikrarsızlık bü- } \\
\text { yümeyi olumsuz etkile- } \\
\text { mektedir. }\end{array}$ \\
\hline $\begin{array}{l}\text { Asteriou ve } \\
\text { Price (2001) }\end{array}$ & 1961-1997 & İngiltere & $\begin{array}{l}\text { Politik İstikrar- } \\
\text { sılılk (Darbe, } \\
\text { Terör, Seçim) }\end{array}$ & $\begin{array}{l}\text { Politik istikrarsızlık bü- } \\
\text { yümeyi olumsuz yönde } \\
\text { etkilemektedir (tek } \\
\text { yönlü nedensellik). }\end{array}$ \\
\hline $\begin{array}{l}\text { Eren ve } \\
\text { Bildirici } \\
(2001)\end{array}$ & $1980-2001$ & Türkiye & $\begin{array}{l}\text { Politik risk, koa- } \\
\text { lisyon hükümet- } \\
\text { leri, seçmenlerin } \\
\text { kararsılı̆̆ı, terör, } \\
\text { siyasi karışıklık }\end{array}$ & $\begin{array}{l}\text { Politik istikrarsızlığın, } \\
\text { düşük büyümeye, enf- } \\
\text { lasyona, düşük yatırı- } \\
\text { ma, kamu harcamala- } \\
\text { rında ve faiz oranında } \\
\text { yükselmeye neden ol- } \\
\text { duğu sonucuna ulaşıl- } \\
\text { miştır }\end{array}$ \\
\hline Feng (2001) & $1978-1988$ & 42 Ülke & Politik belirsizlik & $\begin{array}{l}\text { Politik istikrarsıllık bü- } \\
\text { yümeyi olumsuz yönde } \\
\text { etkilemektedir. }\end{array}$ \\
\hline $\begin{array}{l}\text { Sala-i Mar- } \\
\text { tin (1997) }\end{array}$ & 1960-1992 & $\begin{array}{l}\text { Ülke } \\
\text { Grupları }\end{array}$ & $\begin{array}{l}\text { Politik suikastlar, } \\
\text { etnik ve dilsel } \\
\text { kesimler }\end{array}$ & $\begin{array}{l}\text { Büyüme ile anlamlı bir } \\
\text { ilişki yok }\end{array}$ \\
\hline $\begin{array}{l}\text { Alesina vd. } \\
(1996)\end{array}$ & $1950-1982$ & 113 Ülke & $\begin{array}{l}\text { Politik İstikrar- } \\
\text { sılik }\end{array}$ & $\begin{array}{l}\text { Politik istikrarsızlık bü- } \\
\text { yümeyi olumsuz yönde } \\
\text { etkilemektedir. Bunun- } \\
\text { la birlikte, büyüme ve } \\
\text { gelir üzerinde meydana } \\
\text { gelecek negatif şok po- } \\
\text { litik istikrarsızlığı arttır- } \\
\text { maktadır. }\end{array}$ \\
\hline $\begin{array}{l}\text { Bienen vd. } \\
(1994)\end{array}$ & $1962-1987$ & 39 Ülke & Etnik çatışma & $\begin{array}{l}\text { Ekonomik büyümeden } \\
\text { politik istikrara doğru } \\
\text { bir nedensellik ilişkisi }\end{array}$ \\
\hline $\begin{array}{l}\text { Easterly } \\
\text { ve Rebelo } \\
(1993)\end{array}$ & $\begin{array}{l}1970 \\
1988\end{array}$ & 28 Ülke & $\begin{array}{l}\text { Suikastlar ve } \\
\text { savaş kayıpları }\end{array}$ & Anlamlı bir ilişki yok \\
\hline
\end{tabular}

Kaynak: Bu çalışma için hazırlanmıştır.

Literatür incelendiğinde ampirik çalışmalarla da desteklenen sonuçlar çerçevesinde politik istikrarsızlıkla ekonomik büyüme arasında bir etkileşimin bulunduğu görülmektedir. Bazı çalı̧malarda büyümeden politik istikrarsızlığa doğru; bazı çalışmalardaysa politik istikrarsızlıktan büyümeye doğru bir nedensellik ilişkisinin bulunduğu görülmektedir. Bu çalışmada da literatürden hareketle politik istikrarsılıkla ekonomik büyüme arasındaki neden- 
sellik ilişkisinin yönü nedensellik testlerinden yararlanılarak belirlenmeye çalışılacaktır. Çalışma, kullanılan ekonometrik yöntem ve dönem dikkate alındığında literatürden farklılık arz etmektedir.

\section{Ampirik Uygulama}

Yukarıda değinilen politik istikrarsılık kaynakları ve politik istikrarsızlıkla büyüme arasındaki etkileşim mekanizmaları dikkate alındığında Türkiye'nin büyümesinde ve gelişmesinde en önemli engellerden birinin yaşanılan politik istikrarsızlık ortamı olduğu söylenebilir. Bununla beraber büyüme ve politik istikrarsızlık olgularının karşılıklı olarak birbirlerini etkileme veya ortaya çıkarma olasılıkları dikkate alındığında iki değişken arasındaki nedenselliğin yönünün belirlenmesi önem kazanmaktadır. Bu çalışmada da amaç, nedenselliğin yönünün belirlenmesi ve buna bağlı olarak da politika önerileri getirmektir.

\section{Veri ve yöntem}

Brunetti (1998:122-123) politik istikrarsızlık içerisinde öne çıan unsurlara bağlı olarak politik istikrarsılık göstergelerinin iki farklı kapsamda ortaya konabileceğini ifade etmektedir. Bunlar;

- $\quad$ Politik şiddetin ölçülmesi,

- $\quad$ Hükümet değişikliklerinin ölçülmesi şeklindedir.

Gerek araştırmacılar gerekse kurumlar tarafından temelde yukarıdaki öğeler dikkate alınarak politik istikrarsızlığa ilişkin göstergeler oluşturulmaktadır. Örneğin Türkiye’ye ilişkin Telatar ve Cangir (2014) ve Demirgil (2011) kendi endekslerini oluşturarak çalışmalarında tutarlı sonuçlar elde etmişlerdir.

Kurumlar tarafından oluşturulan endekslere örnek olarak bu çalışmada da tercih edilen Politik Risk Grubu'nca (PRS Group) hazırlanan "Uluslararası Ülke Risk Rehberi” (ICRG-International Country Risk Guide)'den sağlanan "Politik Risk Endeksi" verilebilir. Söz konusu endeks; hükümet istikrarı, sosyo-ekonomik koşullar, yatırım profili, içsel çatışmalar, dışsal çatışmalar, yolsuzluk, politik alanda askerin etkisi, politik alanda dinin etkisi, yasal düzenlemeler, etnik gerilimler, demokratik şeffaflık ve bürokrasi kalitesi olmak üzere 12 alt bileşenden meydana gelmektedir (PRS ty: 3). Alesina ve Weder (1999: 9) söz konusu endeksin akademik çalışmalarda sıklıkla kullanılan bir 
endeks olduğunu belirtmektedirler. Endeksin akademik çalışmalarda yaygın bir şekilde kullanılmasının nedeni; en uzun zaman diliminde, en fazla ülke sayısına yer veren ve çok farklı alt bileşenleri içeren bir endeks olmasıdır. $\mathrm{Bu}$ durum Türkiye örneği ile de uyumludur. Daha önce de ifade edildiği üzere Türkiye'de politik istikrarsızlığın farklı kaynaklardan beslenmesi bu endeksi daha anlamlı hale getirmektedir.

Değişkenlere ilişkin özet bilgiler Tablo 2'de gösterilmiştir. Değişkenler 1987-2015 dönemini içermektedir. Veriler yıllık olarak alınmıştır. Analizlerde Eview 9.0 ve Gauss 10.0 programları kullanılmıştır.

Tablo 2. Değişsenlere İlişkin Bilgiler

\begin{tabular}{llll}
\hline Değişken & Kısaltma & Kaynak & Tanımlama \\
\hline Politik İstikrarsılık & PRI & PRS Group & Politik istikrarsılık \\
Büyüme Oranı & GR & TCMB EVDS & $\begin{array}{l}\text { 1998 Fiyatlarıyla Reel GS- } \\
\text { YH'nın Büyüme Oranı }\end{array}$ \\
\hline
\end{tabular}

Değişkenlere ilişkin tanımlayıcı istatistikler ise Tablo 3'de verilmiştir.

Tablo 3. Değişkenlere İlişkin Tanımlayıcı İstatistikler

Ortalama Ortanca Max. Min. Std. Sapma. Skewness Kurtosis Jarque-Bera

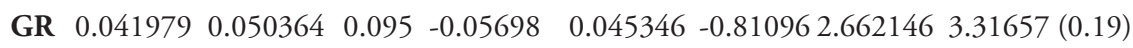

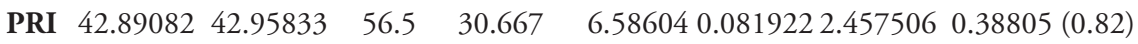

Not: Parantez içerisindeki değer olasılık değerini göstermektedir.

Tablo 4. Korelasyon Matrisi

\begin{tabular}{ccc}
\hline & PRI & GR \\
\hline PRI & 1 & -0.188 \\
\hline GR & -0.188 & 1 \\
\hline
\end{tabular}

Korelasyon matrisi sonuçları incelendiğinde değişkenler arasında zayıf bir ilişkinin bulunduğu görülmektedir. Bununla beraber her iki değişkeni etkileyen birçok faktör bulunduğu dikkate alındığında böyle bir sonucun elde edilmesi de olağandır. 


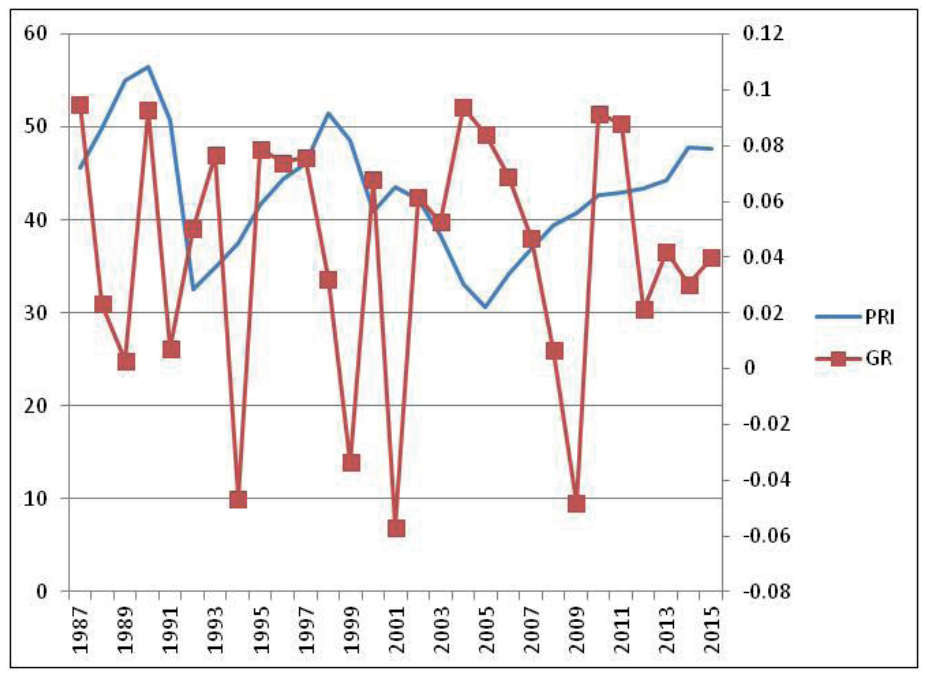

Grafik 1. Büyüme ve Politik Istikrarsızlık

Nedensellik testlerinin metodolojisindeki gelişim süreci incelendiğinde değişkenler arasındaki nedensellik ilişkilerinin mevcudiyeti Granger (1969) tarafından ortaya konulan nedensellik testiyle araştırılmaya başlanmıştır. Aralarındaki nedensellik ilişkisinin varlığı araştırılacak değişkenlerin eşbütünleşik olma şartının bulunması bu testi eşbütünleşme testlerine bağımlı bir konuma getirmiştir. Bu eleştiriye bağlı olarak, birim kök ve eşbütünleşme gibi testlere ihtiyaç olmaksızın nedensellik analizi yapabilmek için farklı yöntemler geliştirilmiştir. Bunlardan biri de Toda ve Yamamoto (1995) nedensellik testidir. Toda-Yamamoto sistem içerisinde yer alan serilerin durağan olmaması durumunda geleneksel F istatistiği standart dağılıma sahip olmayacağından Granger nedensellik testi için kullanılan bu testin sonuçlarının geçerli olmayacağını ortaya koymuşlardır. Ayrıca seriler durağan olmasa dahi serilerin düzey değerlerinin yer aldığı VAR modelinin tahmin edilerek standart MWALD testinin kullanabileceğini belirtmişlerdir. Burada önemli olan modeli doğru bir biçimde saptayarak modeldeki değişkenlerin maksimum bütünleşme derecesinin ve sistemdeki gecikme uzunluğunun doğru bir şekilde belirlenmesidir (Bağdigen ve Beşer 2009:11).

Hacker ve Hatemi J. (2006), VAR modellemesine dayalı MWALD testinin hata terimlerinin normal dağılmaması durumunda hatalı sonuçlar verebileceği şeklindeki eleştirilerine bağlı olarak bu çalışmada da tercih edilen 
Toda-Yamamoto nedensellik testi temelli yeni bir nedensellik testi ortaya koymuşlardır. Örneklem sayısı küçük olduğunda asimptotik dağılım varsayımının geçerli olmaması durumunda leveraged bootstrap simülasyonunun kullanılmasının daha doğru olacağını belirtmektedirler.

Toda-Yamamoto (1995) değişkenlerin durağanlık ve eşbütünleşme derecelerini dikkate almayan $X^{2}$ dağılımına sahip olan WALD testiyle 1 numaralı denklemedeki gösterildiği gibi genişletilmiş $\operatorname{VAR}(\mathrm{p}+\mathrm{d})$ sürecini geliştirmişlerdir (Hacker \& Hatemi-J 2006: 1490-91).

$$
y_{t}=\widehat{v}+\widehat{A}_{1} y_{t-1}+\ldots+\widehat{A}_{p} y_{t-p}+\ldots+\widehat{A}_{p+d} y_{p-t-d}+\widehat{\varepsilon}_{t}
$$

Denklem (1)'de p gecikme uzunluğunu, $\mathrm{d}$ ise maksimum bütünleşme derecesini göstermektedir. Söz konusu model T büyüklüğündeki bir örneklem dikkate alındığında aşağıdaki gibi ifade edilmektedir.

$$
Y=\left(y_{1}, \ldots, y_{T}\right),(n \times T) \text { matrisi, }
$$

$\widehat{D}=\left(v, \hat{A}_{1}, \ldots, \hat{A}_{p}, \ldots \hat{A}_{p+d}\right)$,

$(n \times(1+n(p+d)))$ matrisi,

$$
Z_{t}=\left[\begin{array}{l}
1 \\
y_{t} \\
y_{t-1} \\
\cdot \\
\cdot \\
y_{t-p-d+1}
\end{array}\right]
$$

$((1+n(p+d)) \times 1)$ matrisi, $\mathrm{t}=1, \ldots, \mathrm{T}$ olmak üzere

$$
Z=\left(Z_{0}, \ldots, Z_{T-1}\right)
$$

$((1+n(p+d)) \times T)$ matrisi ve : $\widehat{\delta}=\left(\widehat{\varepsilon}_{1}, \ldots, \widehat{\varepsilon}_{T}\right)(n \times T)$ matrisi olmak üzere, 
Yukarıdaki notasyon kullanılarak tahmin edilen VAR $(\mathrm{p}+\mathrm{d})$ modeli $(\widehat{v})$ sabit terimi göstermek üzere aşağıdaki gibi toplu bir şekilde ifade edilebilir.

$$
Y=\widehat{D} Z+\widehat{\delta}
$$

Toda-Yamamoto (1995), y'nin bir değişkeninin bir başka değişkeninin Granger nedeni olmadığına ilişkin hipotezi test etmek amacıyla 7 numaralı denklemde ifade edilen MWALD testini önermektedirler (Hacker ve Hatemi-J 2006: 1491).

$$
M W A L D=(C \widehat{\beta})^{\prime}\left[C\left(\left(Z^{\prime} Z\right)^{-1} \oplus S_{U}\right) C^{\prime}\right]^{-1}(C \widehat{\beta})
$$

7 numaralı denklemede $\oplus$ Kronecker çarpanını; C, $p \times n(1+n(p+d))$ matrisini göstermektedir. Yukarıdaki denklemler çerçevesinde nedeni olmadığını ifade eden boş hipotez aşağıdaki gibi ifade edilebilir.

$$
H_{0}=C \widehat{\beta}=0
$$

MWALD test istatistiği asimptotik $X^{2}$ dağılımına sahiptir. Hacker ve Hatemi-J örneklem sayısı küçük olduğunda asimptotik dağılım varsayımının geçerli olmaması durumunda kaldıraç (leveraged) bootstrap simülasyonunun kullanılmasının daha doğru olacağını belirtmekte ve bootstrap simülasyonu önermektedirler. Tx1 vektörleri $\mathrm{t}=1, \ldots, \mathrm{T}$ olmak üzere $y_{1 t}$ ve $y_{2 t}$ aşağıda sırasıyla gösterilmektedir. $h_{1}=\operatorname{diag}\left(X_{1}\left(X_{1}^{\prime} X_{1}\right)^{-1} X_{1}^{\prime}\right) \quad$ ve )

$$
h_{2}=\operatorname{diag}\left(X\left(X^{\prime} X\right)^{-1} X^{\prime}\right)
$$

Aşağıda (11) nolu denklemde $h_{i t} h_{i}$ ’nin tìnci öğesi $\tilde{\varepsilon}_{i t}$ ise $y_{i t}$ regresyonunun ham kalıntılarını ve $\mathrm{i}=1,2$ olmak üzere $y_{i t}$,

$$
\tilde{\varepsilon}_{i t}^{m}=\frac{\varepsilon_{i t}}{\sqrt{1-h_{i t}}}
$$

şeklinde gösterilmektedir. Hacker ve Hatemi-J (2006) bootstrap simülasyonunu $800 \mathrm{kez}$ tekrarlamakta, her simülasyonda da MWALD istatistiği üretilmekte ve sonuç olarak bootstrap $\alpha$ kritik $\left(C_{\alpha}^{*}\right)$ değeri elde edilmektedir. Eğer MWALD istatistiği $\left(C_{\alpha}^{*}\right)$ kritik değerinden büyükse bootstrap simülasyonuna dayalı $\mathrm{H}_{0}$ hipotezi reddedilmektedir. 
Granger (1969), Toda-Yamamoto (1995) ve Hacker ve Hatemi-J (2006) nedensellik testleri simetrik nedensellik testleri olup pozitif ve negatif şokların etkilerinin aynı olduğunu kabul etmektedirler. Hatemi-J (2012), asimetrik bilginin bulunması ve ekonomik birimlerin homojen olmaması durumunda ekonomik birimlerin pozitif ve negatif şoklara farklı tepki vermeleri nedeniyle simetrik nedensellik testlerinden elde edilecek sonuçların yanıltıcı olabileceğini iddia etmiştir. Bu eksikliğin giderilmesi amacıyla da Hatemi-J (2012) asimetrik nedensellik testini geliştirmiştir. Bu test Hacker ve Hatemi-J (2006) nedensellik testinin pozitif ve negatif şoklarının ayrıştırılmasına dayanmaktadır.

$y_{1 t}$ ve $y_{2 t}$ gibi iki seri arasında nedensellik ilişkisinin araştırıldığı varsayıldığında (Hatemi-J, 2012: 449);

$$
\begin{aligned}
& y_{1 t}=y_{1 t-1}+\varepsilon_{1 t}=y_{1,0} \sum_{i=1}^{t} \varepsilon_{1 i} \\
& y_{2 t}=y_{2 t-1}+\varepsilon_{2 t}=y_{2,0} \sum_{i=1}^{t} \varepsilon_{2 i}
\end{aligned}
$$

Pozitif ve negatif şoklar denklem (14) ve (15)'deki gösterilebilir.

$\varepsilon_{1 t}^{+}=\operatorname{maks}\left(\varepsilon_{1 t}, 0\right), \quad \varepsilon_{1 t}^{-}=\min \left(\varepsilon_{1 t}, 0\right),($

$\varepsilon_{2 t}^{+}=\operatorname{maks}\left(\varepsilon_{2 t}, 0\right), \quad \varepsilon_{2 t}^{-}=\min \left(\varepsilon_{2 t}, 0\right)$,

$\varepsilon_{1 t}=\varepsilon_{1 t}^{+}+\varepsilon_{1 t}^{-}$ve $\varepsilon_{2 t}=\varepsilon_{2 t}^{+}+\varepsilon_{2 t}^{-}$yazilabilir. Buradan hareketle (12) ve (13) nolu denklemler yeniden düzenlenebilir.

$$
\begin{aligned}
& y_{1 t}=y_{1 t-1}+\varepsilon_{1 t}=y_{1,0} \sum_{i=1}^{t} \varepsilon_{1 i}^{+}+\varepsilon_{1 i}^{-} \\
& y_{2 t}=y_{2 t-1}+\varepsilon_{2 t}=y_{2,0} \sum_{i=1}^{t} \varepsilon_{2 i}^{+}+\varepsilon_{2 i}^{-}
\end{aligned}
$$

Her değişkende yer alan pozitif ve negatif şoklar birikimli olarak denklem (18)'de gösterilmiştir.

$$
y_{1 t}^{+}=\sum_{i=1}^{t} \varepsilon_{1 i}^{+}, \quad y_{1 t}^{-}=\sum_{i=1}^{t} \varepsilon_{1 i}^{-}, \quad y_{2 t}^{+}=\sum_{i=1}^{t} \varepsilon_{2 i}^{+}, \quad y_{2 t}^{-}=\sum_{i=1}^{t} \varepsilon_{2 i}^{-}
$$


Bir sonraki adımda bu bileşenler arasındaki nedensellik ilişkisi test edilir. Sadece pozitif şoklar arasındaki nedensellik ilişkisinin test edildiği dikkate alındığında (negatif şoklar için de aynı süreçler işletilecektir (Hatemi-J 2012: 449); $y_{t}^{+}$değişkeninin $\left(y_{1 t}^{+}, y_{2 t}^{+}\right)$ikilisine eşit olduğu varsayılarak bu bileşenler arasındaki nedensellik ilişkisi aşağıdaki p gecikmeli VAR modeli WALD istatistiği kullanılarak test edilir.

$$
y_{t}^{+}=v+A_{1} y_{t-1}^{+}+\ldots+A_{p} y_{t-1}^{+}+u_{t}^{+}
$$

Denklem (19)'da $y_{t}^{+}, v$ ve $u_{t}^{+}$sırasıyla $2 \mathrm{x} 1$ boyutunda değişken, sabit ve hata terimi vektörlerini göstermektedir. $A_{r}$ ise $2 \times 2$ boyutunda $r$ dereceden, gecikme uzunluğu bilgi kriterleri kullanılarak belirlenen parametre matrisidir.

\section{Ampirik bulgular}

Bir önceki kısımda açıklanan analiz yöntemleriyle çalışmanın amacı doğrultusunda elde edilen ekonometrik analiz bulgularına aşağıda yer verilmiştir.

\section{Birim Kök Testi sonuçları}

Yukarıda da değinildiği üzere Hacker ve Hatemi-J (2006), Toda-Yamamoto (1995) nedensellik testine dayalı olarak geliştirilmiştir. Bu nedenle VAR modelinin gecikme uzunluğu ile kaçıncı dereceden durağan olduğunun belirlenmesi büyük önem taşımaktadır. Bu amaçla ADF (genişletilmiş Dickey-Fuller) ve Phillips-Perron Testleriyle serilerin durağanlık düzeyleri belirlenmiş bulguları Tablo 5'de gösterilmiştir.

Tablo 5. ADF ve PP Birim Kök Testleri

\begin{tabular}{|c|c|c|c|c|c|c|c|}
\hline & Değ. & $\mathrm{ADF}$ & PP & & Değ. & ADF & PP \\
\hline \multirow{4}{*}{$\begin{array}{l}\text { Sabit } \\
\text { Sabit+Trend }\end{array}$} & PRI & $-3.100265(1)^{* *}$ & $-2.039812(3)$ & \multirow{4}{*}{ 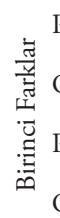 } & PRI & $-3.913439(0)^{*}$ & $-3.807719(3)^{*}$ \\
\hline & GR & $-6.245131(0)^{*}$ & $-9.012666(3)^{*}$ & & GR & $-9.176304(0)^{*}$ & $-21.88526(3)^{*}$ \\
\hline & PRI & $-2.966326(1)$ & $-1.953843(3)$ & & PRI & $-3.927092(0)^{* *}$ & $-3.796472(3)^{* *}$ \\
\hline & GR & $-6.122788(0)^{*}$ & $-8.947195(3)^{*}$ & & GR & $-8.985108(0)^{*}$ & $-21.30510(3)^{*}$ \\
\hline
\end{tabular}

Not: * ve ${ }^{* *}$ değerleri sırasıyla $\% 1$ ve $\% 5$ anlam seviyelerinde serilerin durağanlıklarını göstermektedir. Parantez içindeki değerler ADF için Schwarz bilgi kriterine göre, PP için Bartlett Kernel Newey-West Bandwidth kriterine göre optimal gecikme uzunluğunu göstermektedir. Köşeli parantez içindeki değerler olasılık değerlerini göstermektedir. ADF testi için: 
Mac Kinnon (1996) kritik değerleri sabitte \% 1 ve \% 5 değerleri için sırasıyla -3.69 ve -2.97 ve sabit + trend için $\% 1$ ve $\% 5$ olasılık değerleri için sırasıyla -4.33 ve -3.58 . PP testi için: Mac Kinnon (1996) kritik değerleri sabitte \% 1 ve \% 5 değerleri için sırasıyla -3.69 ve -2.97 ve sabit +trend için $\% 1$ ve $\% 5$ olasılık değerleri için sırasıyla -4.32 ve -3.58 .

Tablo 5 incelendiğinde PRI değişkeni gerek sabitli ve trendsiz ADF ve PP birim kök testlerinin gerekse sabitli ve trendli ADF ve PP birim kök testlerinin sonuçlarına göre serilerin düzey değerleri açısından $\mathrm{ADF}$ ve $\mathrm{PP}$ test istatistiklerinin mutlak değeri, Mac-Kinnon kritik değerinin mutlak değerinden küçük olduğundan birim kök içerdiği yani durağan olmadığı sonucuna varılmıştır (PRI serisi ADF testine göre sabitli-trendsiz durumda düzeyde durağan çımıştır). ADF ve PP birim kök testi sonuçlarına göre GR serisinin ise düzeyde durağan olduğu bir başka ifadeyle birim kök içermediği görülmektedir. Dolayısıyla büyüme serisinde meydana gelecek şokların kalıcı olmadığı kısa dönemde ortalama değerine geri döneceği ifade edilebilir.

\section{Nedensellik Testi sonuçlar}

İlk olarak değişkenlerin maksimum bütünleşme derecesini belirlemek amacıyla ADF ve PP bütünleşme testleri yardımıyla durağanlık düzeyleri belirlenmiştir. Gerek Hacker ve Hatemi-J (2006) gerekse Hatemi-J (2012) nedensellik testlerinde VAR modellerinde kullanılacak olan gecikme saylarının doğru bir şekilde tespit edilmesi büyük önem taşımaktadır. Hacker ve Hatemi-J (2006)'da gecikme uzunluğunun disssal olarak belirlenmesi bir zayıflık olarak görülmüştür. Araştırmacılar söz konusu zayıflığı gidermek amacıyla Hacker ve Hatemi-J (2012) testini geliştirmişlerdir. Böylece gecikme uzunluğunun içsel olarak belirlenmesi sağlanmıştır. Bu süreçte kullanılan Schwarz Bayesian Bilgi Kriteri (SBC) aşağıdaki denklem yardımıyla hesaplanmaktadır (Hacker \& Hatemi-J 2012:147).

$$
S B C=\operatorname{Ln}\left(\operatorname{det} \bar{\Omega}_{j}\right)+k\left(\frac{n^{2} L n T}{T}\right)
$$

20 numaralı denklemde $\bar{\Omega}_{j}$; varyans-kovaryans matrisinin determinantını, k; gecikme uzunluğunu, T; gözlem sayısını göstermektedir.

Modellere ilişkin Hacker ve Hatemi-J nedensellik testinin bulguları Tablo 6'da gösterilmektedir. 
Tablo 6. Hacker ve Hatemi (2006) Nedensellik Testi Sonuçları

\begin{tabular}{|c|c|c|c|c|c|c|c|c|c|}
\hline \multirow{2}{*}{ Nedensellik } & \multirow{2}{*}{$\begin{array}{l}\text { MWALD } \\
\text { Test İst. }\end{array}$} & \multicolumn{3}{|c|}{$\begin{array}{l}\text { Bootstrap } \\
\text { MWALD }\end{array}$} & \multirow{2}{*}{\multicolumn{2}{|c|}{ Nedensellik $\begin{array}{c}\text { MWALD } \\
\text { Test İst. }\end{array}$}} & \multicolumn{3}{|c|}{ Bootstrap MWALD } \\
\hline & & $\% 1$ & $\% 5$ & $\% 10$ & & & $\% 1$ & $\% 5$ & $\% 10$ \\
\hline GR PRI [1] & $\begin{array}{l}3.408^{* * *} \\
(0.065)\end{array}$ & 21.92 & .389 & 3.282 & PRI GR[1] & $\begin{array}{l}0.447 \\
(0.504)\end{array}$ & 14.454 & 4.531 & 3.113 \\
\hline
\end{tabular}

Not: ${ }^{* * *} \% 10$ İstatistik anlamlılık düzeyini göstermektedir. Köşeli parantez içinde gösterilen Optimal Gecikme Uzunluklarının belirlenmesinde SBC kriteri kullanılmıştır. Parantez içindeki değerler asimptotik $X^{2}$ olasılık değerlerini göstermektedir. Bootstrap kritik değerleri 1000 tekrar sonucunda elde edilmiştir.

Hacker ve Hatemi-J (2006) bootstrap nedensellik testi sonuçlarına göre büyümeden politik istikrarsızlığa doğru bir nedensellik ilişkisinin var olduğu sonucuna ulaşılmıştır. Bu sonuç Aslan (2011), Şanlısoy ve Kök (2010b) ve Telatar (2003) ile uyumludur. Söz konusu nedensellik testi değişkenler arasında nedensellik ilişkisinin varlığına ilişkin bilgi vermekle birlikte değişkenlerden birindeki değişimin diğerini aynı yönde mi yoksa ters yönde mi etkilediği konusunda bilgi vermemektedir. Çalışmada değişkenler arasındaki söz konusu ilişkinin yönünü belirleyebilmek amacıyla Hatemi-J (2012) asimetrik nedensellik testi kullanılmış ve sonuçlar Tablo 7'de gösterilmiştir.

Tablo 7. Hatemi-J Asimetrik Nedensellik Testi Sonuçları

\begin{tabular}{|c|c|c|c|c|c|c|c|c|c|}
\hline \multirow{2}{*}{$\begin{array}{l}\text { Neden- } \\
\text { sellik }\end{array}$} & \multirow{2}{*}{$\begin{array}{l}\text { MWALD } \\
\text { Test İst. }\end{array}$} & \multicolumn{3}{|c|}{ Bootstrap MWALD } & \multirow{2}{*}{$\begin{array}{l}\text { Neden- } \\
\text { sellik }\end{array}$} & \multirow{2}{*}{$\begin{array}{c}\text { MWALD } \\
\text { Test İst. }\end{array}$} & \multicolumn{3}{|c|}{ Bootstrap MWALD } \\
\hline & & $\% 1$ & $\% 5$ & $\% 10$ & & & $\% 1$ & $\% 5$ & $\% 10$ \\
\hline \multirow{2}{*}{$\begin{array}{c}\mathrm{GR}^{+} \\
\mathrm{PRI}^{+}[2]\end{array}$} & & \multirow[t]{2}{*}{66.715} & \multirow[t]{2}{*}{22.654} & \multirow[t]{2}{*}{12.593} & \multirow{2}{*}{$\begin{array}{c}\mathrm{PRI}^{+} \\
\mathrm{GR}^{+}[2]\end{array}$} & 0.790 & \multirow[t]{2}{*}{58.043} & \multirow[t]{2}{*}{20.511} & \multirow[t]{2}{*}{11.691} \\
\hline & $(0.000)$ & & & & & $(0.674)$ & & & \\
\hline \multirow{2}{*}{$\begin{array}{l}\mathrm{GR}^{+} \\
\text {PRI- }^{-}[1]\end{array}$} & 0.158 & \multirow[t]{2}{*}{15.208} & \multirow[t]{2}{*}{5.725} & \multirow[t]{2}{*}{3.408} & \multirow{2}{*}{$\begin{array}{c}\mathrm{PRI}^{+} \\
\mathrm{GR}^{-}[1]\end{array}$} & 2.147 & \multirow[t]{2}{*}{18.182} & \multirow[t]{2}{*}{7.049} & \multirow[t]{2}{*}{4.111} \\
\hline & $(0.691)$ & & & & & $(0.143)$ & & & \\
\hline \multirow{2}{*}{$\begin{array}{l}\mathrm{GR}^{-} \\
\text {PRI- }^{-}[1]\end{array}$} & 0.434 & \multirow[t]{2}{*}{18.528} & \multirow[t]{2}{*}{6.523} & \multirow{2}{*}{\multicolumn{2}{|c|}{$\begin{array}{c}3.918 \mathrm{PRI}^{-} \mathrm{GR}^{-} \\
{[1]}\end{array}$}} & 0.000 & \multirow[t]{2}{*}{11.932} & \multirow[t]{2}{*}{6.285} & \multirow[t]{2}{*}{3.728} \\
\hline & $(0.510)$ & & & & & $(0.990)$ & & & \\
\hline \multirow{2}{*}{$\begin{array}{c}\mathrm{GR}^{-} \\
\mathrm{PRI}^{+}[1]\end{array}$} & 2.555 & \multirow[t]{2}{*}{13.237} & \multirow[t]{2}{*}{6.449} & \multirow[t]{2}{*}{3.994} & \multirow{2}{*}{$\begin{array}{c}\mathrm{PRI}^{-} \\
\mathrm{GR}^{+}[1]\end{array}$} & 0.052 & \multirow[t]{2}{*}{16.031} & \multirow[t]{2}{*}{6.717} & \multirow[t]{2}{*}{3.675} \\
\hline & $(0.110)$ & & & & & $(0.820)$ & & & \\
\hline
\end{tabular}

Not: ${ }^{*} \% 1$ istatistik anlamlılık düzeyini göstermektedir. Köşeli parantez içinde gösterilen Optimal Gecikme Uzunluklarının belirlenmesinde SBC kriteri kullanılmıştır. Parantez içindeki değerler asimptotik $X^{2}$ olasılık değerlerini göstermektedir. Bootstrap kritik değerleri 1000 tekrar sonucunda elde edilmiştir. 
Asimetrik nedensellik testi sonuçlarına göre büyüme üzerine gelen pozitif bir şok politik istikrarsızlık üzerinde pozitif bir şok yaratmaktadır. Bir başka ifadeyle büyüme oranındaki artış politik istikrarsızlığı artırmaktadır.

Elde edilen bu sonuçlar toplu olarak değerlendirildiğinde nedensellik ilişkisinin varlığının kabulü açısından literatürle uyumlu olmakla birlikte, literatürden farklı olarak ve literatüre bir katkı niteliğinde Türkiye'de büyüme oranlarındaki artışın politik istikrarsızlığı artırdığı sonucuna ulaşılmıştır. Elde edilen bu sonuç teorik beklentilerden farklıdır. Bununla beraber bu durum gerek bölüşüm ilişkilerine gerekse jeopolitik ve jeostratejik önemi sebebiyle bölgede güçlü bir Türkiye'nin istenmemesine bağlı olarak Türkiye’ye özgü koşullarla açıklanabilir.

\section{Sonuç ve Politika Önerileri}

Çalışmanın bulguları değerlendirildiğinde literatürle uyumlu bir şekilde politik istikrasızlıkla büyüme arasında bir nedensellik ilişkinin bulunduğu görülmektedir. Bununla beraber Türkiye’ye ilişkin çalışmalardan farklı olarak bu çalışmada ekonomik büyümede meydana gelen pozitif şokların politik istikrarsılılk üzerinde pozitif bir şok oluşturmak suretiyle politik istikrarsızlığı artırdığı bulgusu elde edilmiştir. Bu sonuç Türkiye’ye özgü koşullarla açılklanabilir.

Büyüme sürecinde artan gelirin sosyal gruplar arasındaki paylaşımının nasıl olacağı bir anlamda paylaşım savaşlarına bağlı olarak oluşacaktır. Özellikle adaletten giderek uzaklaşan bir paylaşım gruplar arasındaki çatışmayı tırmandırarak politik istikrarsızlığı artırabilecektir. 1987 ve 1994 hane halkı gelir dağılımı anketi sonuçlarının da desteklediği üzere gelir dağılımındaki adaletsizlik diğer ekonomik sorunlarla birleşerek halkı yeni arayışlara itmiş ve bu da koalisyon hükümetlerini ortaya çıkarmıştır. Ayrıca 2002 sonrasında tek parti iktidarının sağladığı güç ile beraber gerçekleştirilen reformlar ve küresel ekonomik koşulların da iyi gitmesine bağlı olarak elde edilen yüksek ekonomik büyüme performans, paylaşım ilişkilerine bağlı olarak yeni bir zengin sınıf yaratmıştır. Bu ise yeni bir paylaşım kavgasını hatta ideolojik temelde bir kutuplaşmayı beraberinde getirmiş ya da derinleştirmiştir.

Türkiye’ye özgü bir başka olgu jeopolitik ve jeostratejik önemine bağlı olarak ortaya çıkmaktadır. Türkiye istikrarlı bir büyüme performansı yakaladığı dönemlerde ya da güçlendiğinde ülkede birtakım karışılıklar çıkarılarak 
kaos ortamı yaratılmaya çalışılmaktadır. Gerek tarihsel süreç bu yönüyle ele alındığında gerekse 2010 sonrasında ülkede yaşanan sıkıntılar incelendiğinde bu karışıklıklarda yurtdışı bağlantılarının olduğu gerek devlet adamlarımız gerekse araştırmacılar tarafından sıklıkla dile getirilmektedir. Bu noktada yapılacak olan millet olma şuurunun da gücü ile kararlı ve dik duruşun tüm dünyaya gösterilmesidir.

Politik alanın iç dinamiklerine bağlı olarak 90'lı yıllarda ortaya çıkan politik istikrarsızlık dikkate alındığında 2002 yılıyla birlikte koalisyon hükümetlerinin ardından tek parti hükümetinin iktidara gelmesi politik istikrarın sağlanması anlamında önemli bir ilerlemedir. Politik istikrarsızlık olgusu sosyal gruplar ve politik rakipler açısından ele alındığında 2000'li yılların sonlarından itibaren politik kutuplaşma ve toplumsal ayrışmanın belirgin bir hal alması politik istikrarsızlığı arttırdığı gibi orta ve uzun vadede de potansiyel bir istikrarsızlık beklentisini beraberinde getirmiştir. Politik istikrarsızlığı ortaya çıkaran iç unsurların gerekli hukuksal düzenlemelerle çözümlenmesine, tüm toplum açısından demokrasi ve uzlaşma kültürünün içselleştirilmesine, tüm siyasi partiler açısından parti içi demokrasiye işlerlik kazandırılmasına ihtiyaç duyulduğu belirgin bir şekilde ortadadır. Elde edilen bulgular dikkate alındığında hedeflenen büyüme sürecinde bir yandan sosyal grupların diğer yandan ise iktidar ve muhalefetiyle birlikte siyasal partilerin uzlaşmacı bir tavır içerisinde olmalarının gerekliliği ülkenin geleceği göz önüne alındığında oldukça önemlidir. Bu alanlarda atılacak adımların ülkedeki refah artışılla birlikte uluslararası arenada daha güçlü ve gelişmiş bir Türkiye’nin varlığını belirgin şekilde hissettireceği ifade edilebilir.

Türkiye ekonomisinin yapısal koşulları dikkate alındığında; ithal girdi bağımlılığı, finansal yatırımlara dayalı büyüme, yabancı finansal sermaye akımları gibi yapısal sorunların bulunduğu ifade edilebilir. Bu durum Türkiye’yi özellikle dış kaynaklı ekonomik ve politik istikrarsızlı̆ga daha açık ve kırılgan hale getirmektedir. Bu, politik istikrara rağmen küresel şoklara bağlı ekonomik istikrarsızlığı beraberinde getirebilmektedir. Dolayısıyla büyüme ve gelişme sürecinde özellikle teknolojik yeniliklerin yaratılmasına imkân sağlayacak mekanizmaların oluşturularak dışa bağımlılığın azaltılması, çağın gereklerine uygun olarak bilgi işçilerinin yetiştirilmesine yönelik eğitim politikalarının oluşturulması ve yenilenmesi önemlidir. Bütün bunlar reel dinamiklere dayalı kalııı bir ekonomik büyümeyi ve karşılıklı etkileşim 
ilişkisi dikkate alındığında politik istikrarı beraberinde getirecektir. Böylece Türkiye, ortalama refah seviyesi daha yüksek, gerek ekonomik gerekse politik açıdan daha güçlü, dolayısıyla uluslararası arenada lider bir ülke konumuna gelebilir.

\section{Kaynaklar}

Acemoğlu, Daron ve Murat Üçer (2015). The Ups and Downs of Turkish Growth, 2002-2015. NBER.

Aisen, Ari \& Francisco José Veiga (2013). "How Does Political Instability Affect Economic Growth". European Journal of Political Economy 29: 151-167.

Alesina, Alberto \& Beatrice Weder (1999). Do Corrupt Governments Receive Less Foreign Aid. NBER.

Alesina, Alberto \& Roberto Perotti (1993). Income Distribution, Political Instability, and Investment. NBER. Cambridge.

Alesina, Alberto, Şule Özler, Nouriel Roubini \& Phillip Swagel (1996). "Political Stability and Economic Growth". Journal of Economic Growth 1(2): 189-211.

Arınç, Kenan (2010). "Siyasi ve Tarihi Coğrafya Perspektifiyle: Türkiye'nin Terör Sorununun Analizi ve Jeopolitik-Jeostratejik Açıdan Değerlendirilmesi”. Atatürk Üniversitesi SBE Dergisi 14 (2):1-34.

Arslan, Ünal (2011). "Siyasi İstikrarsızlık ve Ekonomik Performans: Türkiye Örneği”. Ege Akademik Bakı̧ 11(1): 73-80.

Artan, Seyfettin ve Pınar Hayaloğlu (2014). "Kurumsal Yapı ve İktisadi Büyüme İlişkisi”. Sosyoekonomi 2: 347-364.

Asteriou, Dimitrios \& Simon Price (2001). "Political Instability and Economic Growth: UK Time Series Evidence". Scottish Journal of Political Economy 48 (4): 383-399.

Atay, Mehmet (2008). "Türkiye'de Terörü Ortaya Çıkaran İç ve Dış Dinamikler, Stratejiler ve Taktikler" HÜTAD Türkiyat Araşttrmalar Dergisi 8: 409-424.

Bağdigen, Muhlis ve Berna Beşer (2009). "Ekonomik Büyüme ile Kamu Harcamaları Arasındaki Nedensellik İlişkisinin Wagner Tezi Kapsamında Bir Analizi: Türkiye Örneği”. Zonguldak Karaelmas Üniversitesi Sosyal Bilimler Dergisi 5 (9): 1-17.

Bienen, Henry, John Londregan \& Nicolas Van de Walle (1994). "Ethnicity, Leadership Succession, and Economic Development in Africa". 1993 Working Paper Series: Executive Summaries. Institute for Policy Reform: Washington, D.C.

Brunetti, Aymo (1998). "Political Variables in Growth Regressions". Volatility, Uncertainty, Instability and Growth. http://www.rrojasdatabank.org/borner/ borner6.pdf (Erişim Tarihi :15.06.2007) 
Butkiewicz, James \& Halit Yanıkkaya (2005). "The Impact of Sociopoliticial Instability on Economic Growth: Analysis and Implications". Journal of Policy Modeling 27 (5): 629-645.

Campos, Nauro F. \& Jeffrey B. Nugent (2002). "Who is Afraid of Political Instability?”. Journal of Development Economics 67: 157-172.

Demirgil, Hakan (2011). "Politik İstikrarsızlık, Belirsizlik ve Makroekonomi: Türkiye Örneği (1970-2006)”. Marmara Üniversitesi İI.I.B.F. Dergisi 31: 123-144.

Doğan, Adem (2005). "Demokrasi ve Ekonomik Gelişme”. Erciyes Üniversitesi İktisadi ve İdari Bilimler Fakültesi Dergisi 25: 1-19.

Easterly, William \& Sergio Rebelo (1993). "Fiscal Policy and Economic Growth". Journal of Monetary Economics 32: 417-458.

Engle, F. Robert \& W.J. Clive Granger (1987). “Cointegration and Error Correction: Representation, Estimation and Testing”. Econometrica 55: 251-276.

Eren, Ercan ve Melike Bildirici (2001). “Türkiye’de Siyasal ve İktisadi İstikrarsızlık; 1980-2001”. İşletme ve Finans 187: 27-33.

Erkal, Gökhan, Merter Akıncı ve Ömer Yılmaz (2015). "Politik İstikrarsızlık ve Yolsuzluk İlişkisi: Bir Panel Analizi”. Ege Akademik Bakış 15 (3): 327-342.

Feng, Yi (2001). "Political Freedom, Political Instability and Policy Uncertainty: A Study of political Institutions and Private Investment in Developing Countries". International Studies Quaterly 45: 271-294.

Giles, Judith A. \& Cara L. Williams (1999). "Export-led Growth: a Survey of the Emprical Literature and Some non-causality Results". Economertic Working Paper EWP9901. Canada: Department of Economics University of Victoria. $1-29$.

Goesjenova, Mina (2013). “The Effect of Ethnic Conflict and Political Instability on Import Demand: Evidence from Turkey”. MARBLE Research Papers 6: 35-60. Granger, W. J. Clive (1969). "Investigating Causal Relations by Econometric Models and Cross-Spectral Methods". Econometrica 37 (3):424-438.

Grilli, Vittorio, Donato Masciandaro \& Guido Tabellini (1991). "Political and Monetary Institutions and Public Financial Policies in the Industrial Countries”. Economic Policy 6 (13): 342-392.

Gür, Timur Han ve Hale Akbulut (2012). "Gelişmekte Olan Ülkelerde Politik İstikrarın Ekonomik Büyüme Üzerine Etkisi”. Sosyoekonomi 1: 282-300.

Hacker, R. Scott ve Abdulnasser Hatemi-J (2006). "Tests for Causality between Integrated Variables Using Asymptotic and Bootstrap Distributions: Theory and Application". Applied Economics 38 (13): 1489-1500.

Hacker, R. Scott. \& Abdulnasser Hatemi-J (2012). "A Bootstrap Test for Causality with Endogenous Lag Length Choice: Theory and Application in Finance". Journal of Economic Studies 39 (2): 144-160. 
Hatemi-J, Abdulnasser (2012). "Asymmetric Causality Tests with an Application". Empirical Economics 43 (1): 447-456.

İnsel, Ahmet (1991). “Siyasal Bir Süreç Olarak İktisadi Kalkınma II”. Birikim 21: $12-23$.

Jarosiewicz, Aleksandra (2013). “Turkey's Economy: A Story of Success with an Uncertain Future". OSW Commentary 120: 1-6.

Karahan, Hatice ve Erdal Tanas Karagöl (2014). "Ekonomik Performansın Temel Taşı: Siyasi İstikrar”. Seta Perspektif 41.

Kök, Recep, Ramazan Ekinci ve A. Elif Ay Yalçınkaya (2015). "Ülke Riski Bileşenlerinin Bankacılık ve Reel Sektör Üzerine Etkileri: Türkiye Örneği, 1993-2015”. Çukurova Üniversitesi İİBF Dergisi 19 (2): 151-171.

Kurzman, Charles, Regina Werum \& Ross E. Burkhart (2002). "Democracy's Effect on Economic Growth: A Pooled: Time-Series Analysis, 1951-1980”. Studies in Comparative International Development 37 (1): 3-33.

Kuznets, Simon (1955). "Economic Growth and Income Inequality". The American Economic Review 45 (1): 1-28.

Leahy John V. \& Toni M. Whited (1996). “The Effect of Uncertainity on Investment Some Stylized Facts". Journal of Money, Credit and Banking 28 (1): 64-83.

Lensink, Robert, Niels Hermes \& Victor Murinde (2000). "Capital Flight and Political Risk". Journal of International Money and Finance 19: 79-92.

Mo, Pak H. (2001). "Corruption and Economic Growth". Journal of Comparative Economics 29 (1): 66-79.

Murphy, Kevin, Andrei Shleifer \& Robert W. Vishny (1991). “The Allocation of Talent: Implications for Growth”. Quarterly Journal of Economics 106: 503530 .

Özsağır, Arif (2013). “Askeri Darbe ve Müdahalelerin Ekonomik Performans Üzerine Etkisi: Türkiye Örneği”. Gaziantep University Journal of Social Sciences 12 (4): 759-773.

Öztürk, Hüseyin (2004). Siyasi İstikrarsızlık ve Ekonomi Üzerindeki Etkileri: Türkiye Uygulaması (1950-2003). Yüksek Lisans Tezi. Isparta: Süleyman Demirel Üniversitesi.

Parlakyıldız, Merve (2015). "Makro Ekonomik ve Politik İstikrarsılı̆̆ın Ekonomik Performans Üzerine Etkisi: Latin Amerika Örneği”. Çukurova Üniversitesi İ̇BF Dergisi 19 (2): 1-11.

Persson, Torsten \& Guido Tabellini (2002). Political Economics. The MIT Press.

Romer, David (1996). Advanced Macroecenomics. McGraw -Hill: Singapore

Sakamato, Takayuki (2005). "Economic Performance of 'Weak' Governments and Their Interaction with Central Banks and Labour: Deficits, Economic Growth, Unemployment and Inflation, 1961-1998”. European Journal of 
Political Research 44 (6): 801-836.

Sala-i Martin \& Xavier X. (1997). "I Just run Four Million Regressions". NBER Working Paper No: 4186.

Sandıklı, Atilla (2013). "Yumuşak Güç Savaşları ve Gezi Parkı Olayları”. Her Yönüyle Dernekler Dergisi 25 (4). http://www.bilgesam.org/incele/605/-yumusakguc-savaslari-ve-gezi-parki-olaylari/\#.WGJunVOLRnI (Erişim Tarihi: 27.12.2016).

Şanlısoy, Selim ve Recep Kök (2010a). "Politik İstikrarsızlık - Ekonomik Büyüme İlişkisi: Türkiye Örneği (1987-2006)”. Dokuz Eylül Üniversitesi İktisadi ve İdari Bilimler Fakültesi Dergisi 25 (1): 101-125.

Şanlısoy, Selim ve Recep Kök (2010b). "Politik İstikrarsızlık Ekonomik Büyüme İlişkisi: Kuznets Eğrisi Yaklaşımı”. Finans Politik \& Ekonomik Yorumlar 47 (541): 9-22.

Tan, Mehmet (2008). Türkiyéde Askeri Darbelerin Siyasal Istikrar Üzerine Üzerindeki Etkileri. Doktora Tezi. İstanbul: Marmara Üniversitesi.

Tansel, Aysıt ve Nil Demet Güngör (2003). “Türkiye'den Yurt Dışına Beyin Göçü: Amprik Bir Uygulama”. II. Bilgi, Ekonomi ve Yönetim Kongresi. İzmit. 697708.

Telatar, Erdinç ve Funda Telatar (2004). "Standart IMF İstikrar Politikaları: Politik İstikrarsızlığa Yol Açan Bir Kanal”. İşletme ve Finans 215: 53-65.

Telatar, Erdinç ve Niyazi Cangir (2014). “Türkiye İçin Politik İstikrarsızlık Endeksleri: 1955-2009 Dönemi”. Sosyoekonomi 21 (21): 9-30.

Telatar, Funda (2003). “Türkiye'de Politika Değişkenliği ile Ekonomik Büyüme Arasındaki Nedensellik İlişkileri”. İşletme ve Finans 211: 71-91.

The PRS Group (Belirtilmemiş). ICRG Methodology.

Toda, Hiro Y. \& Taku Yamamoto (1995). "Statistical Inference in Vector Autoregressions with Possibly Integrated Processes". Journal of Econometrics 66 (2): 225-250.

UNDP (2002). Human Development Report 2002: Deepening Democracy in a Fragmented World. New York:

Yalçınkaya, Ayşe Elif Ay, Selim Şanlısoy ve Üzeyir Aydın (2016). “Türk Bankacılık Endüstrisinde Performansın Belirleyenleri ve Politik İstikrarsızlık". Sosyoekonomi 24 (27): 161-182.

Yayla, Atilla (2016). “On Turkey's Classical Revolution of July 15”. Bilig - Türk Dünyası Sosyal Bilimler Dergisi 79: 159-172.

Yayla, Atilla. "İstikrarsızlığa İhtiyacımız Var". www.liberal-dt.org.tr/yayla/ayistikrarsôzlók.htm (Erişim Tarihi: 27.12.2016). 


\title{
The Realtionship between Political Instability and Economic Growth in Turkey: A Causality Analysis*
}

\section{Selim Şanlısoy ${ }^{* *}$}

\begin{abstract}
The aim of this study is to analyze the existence of the relationship between the political instability and economic growth for the period between 1987 and 2015 in the Turkish economy. According to results of the symmetric and asymmetric causality tests the evidence for the existence of the positive shock effects over the political instability caused by the positive shocks in the economic growth has been achieved in contradistinction to the literature. This situation can be explained either through the conflicts of interests within the frame of distribution relationships and through the attempts of rival countries to weaken the Turkey within the frame of geopolitical and geostrategic importance she has. From this point of view it can be expressed that it is very important for reconciliation and tolerance to be hegemon in the political field and the existence of public organization that maintain a firm stand against external powers to actualize a faster growing and developped Turkey. A new balance of power can be formed in which the Turkey take a leading role regionally when these facts are combined with the policies that eliminate the structural problems of the Turkish economy.
\end{abstract}

\section{Keywords}

Political instability, economic growth, Hacker-Hatemi-J Causality Test, Hatemi-J Asymmetric Causality Test.

JEL Classification Codes: E6, H1, O4

\footnotetext{
Date of Arrival: 10 October 2016 - Date of Acceptance: 04 July 2017 You can refer to this article as follows:

Şanlısoy, Selim (2020). “Türkiye’de Politik İstikrarsızlık ile Ekonomik Büyüme İlişkisi: Bir Nedensellik Analizi”. bilig - Journal of Social Sciences of the Turkic World 92: 85-114.

** Assoc.Prof. Dr., Dokuz Eylül University, Faculty of Economics and Administrative Sciences, Department of Economics - İzmir/Turkey

ORCID ID: orcid.org/0000-0002-0629-0905

selim.sanlisoy@deu.edu.tr
} 


\section{Связь между политической нестабильностью и экономическим ростом в Турции: анализ причинности}

\section{Селим Шанлысой ${ }^{\text {** }}$}

\section{Аннотация}

Целью данного исследования является анализ существования взаимосвязи между политической нестабильностью и экономическим ростом в Турции в период между 1987 и 2015 годами. Проведенные ради целей исследования симметричные и асимметричные тесты причинности показали результаты, отличные от опубликованных в литературе, доказывающие существование положительных шоковых эффектов от политической нестабильности, оказывающихся положительными шоками, влияющими на экономический рост. Эта ситуация может быть объяснена попытками конкурирующих стран ослабить Турцию, используя конфликты интересов в рамках распределительных отношений, с учетом геополитического и геостратегического значения Турции. С этой точки зрения можно сказать, что для быстро развивающейся Турции очень важно существование общественной силы, которая имеет твердую позицию в отношении внешних сил, и проводит в политической сфере культуру для примирения и доброй воли. Если эти факторы будут объединены с политикой, которая устранит структурные проблемы турецкой экономики, может сформироваться новый баланс сил, в котором Турция будет играть ведущую роль на региональном уровне.

\section{Ключевые слова}

политическая нестабильность, экономический рост, тест причинности Хакера-Хатеми-Ј, тест асимметричной причинности Хатеми-Ј.

Классификационные коды JEL: E6, H1, O4

\footnotetext{
* Поступило в редакцию: 10 октябрь 2016 г. - Принято в номер: 04 июля 2017 г.

Ссылка на статью:

Şanlısay, Selim (2020). “Türkiye'de Telekomünikasyon Altyapısı ve Ekonomik Büyüme”. bilig Journal of Social Sciences of the Turkic World 92: 85-114.

** Доц., д-р, Университет Девятого Сентября, факультет экономики и управления, кафедра экономики - Измир / Турция

ORCID ID: orcid.org/0000-0002-0629-0905

selim.sanlisoy@deu.edu.tr
} 